\title{
Differentiation of Pathogenic Groups of Xylella fastidiosa Strains with Whole-Cell Protein Profiles
}

\author{
R. L. Wichman and D. L. Hopkins, University of Florida, Mid-Florida Research and Education Center, 2725 Bin- \\ ion Road, Apopka 32703
}

\section{ABSTRACT}

Wichman, R. L., and Hopkins, D. L. 2002. Differentiation of pathogenic groups of Xylella fastidiosa strains with whole-cell protein profiles. Plant Dis. 86:875-879.

Whole-cell protein analyses of 75 Xylella fastidiosa strains by sodium dodecyl sulfatepolyacrylamide gel electrophoresis were compared, and variations in the protein banding patterns among the strains were observed. Based on the presence, absence, or difference in intensity of 10 protein bands within the 21.5 to $45.0 \mathrm{kDa}$ molecular mass range, the strains could be subdivided into four distinct pathogenic groups and two miscellaneous groups whose members were pathogenic to various different hosts. Group 1 was the Pierce's disease of grapevine pathogenic group. Although 4 of these 45 strains had hosts of origin other than grapevine, they all produced Pierce's disease symptoms. Uniform, distinct protein profiles also occurred with group 2 (elderberry leaf scorch strains), group 3 (oak leaf scorch strains), and group 4 (oleander leaf scorch strains). Groups 5 and 6 were made up of strains pathogenic to almond, blackberry, lupine, mulberry, periwinkle, elm, and plum. Thus, whole-cell protein analysis was shown to be a rapid and consistent method for identifying four pathogenic groups of $X$. fastidiosa strains.

Described strains of the genus Xylella make up a single species, Xylella fastidiosa (30). These strains cause diseases that result in large losses in many economically important agricultural plants, including grapevine, peach, plum, coffee, and citrus (10). X. fastidiosa also causes leaf scorch and declines in many urban shade trees and shrubs, such as elm, oak, oleander, maple, and sycamore (12). Some strains of $X$. fastidiosa, such as Pierce's disease of grapevine, have very wide host ranges; however, many of the hosts may be symptomless (11). The most important vectors of $X$. fastidiosa are members of the leafhopper subfamily Cicadellinae (sharpshooters) and of the spittlebug family Cercopidae (23). Similar to the bacterium, these vectors have very wide host ranges, consisting of both woody and herbaceous plants.

While all strains of Xylella have been classified into a single species (30), there are different pathotypes and possibly different subspecies $(13,24)$. Most of the pathotypes have not been characterized and compared with each other. Confusing the issue even more is the probability that genetically distinct strains of the bacterium may produce similar symptoms in a com-

Corresponding author: D. L. Hopkins

E-mail: dhop@gnv.ifas.ufl.edu

Florida Agricultural Experiment Station Journal Series No. R-08094.

Accepted for publication 10 April 2002.

Publication no. D-2002-0528-05R

(C) 2002 The American Phytopathological Society mon host $(17,19)$. Based on nutritional fastidiousness (16), enzyme-linked immunosorbent assay (ELISA) (8), and the polymerase chain reaction (PCR) (20), strains can be separated into two distinct groups, the Pierce's disease of grape group and a miscellaneous group sometimes called the phony peach group (15). In the phony peach group, there appear to be several different pathotypes that have not been characterized, and pathogenicity tests with some of these tree strains require 18 to 24 months to complete. Only the citrus variegated chlorosis pathotype can be quickly identified using PCR. A set of PCR primers (CVC-1 and 272-2-int) was developed that are specific for strains of $X$. fastidiosa that cause citrus variegated chlorosis and/or coffee leaf scorch (22).

Pathogenic relationships among strains of $X$. fastidiosa are not very well understood, especially in the phony peach group, and appear to be very complex. Limited reciprocal transmission tests have been conducted with $X$. fastidiosa strains. Pierce's disease of grape, almond leaf scorch, and alfalfa dwarf were shown to be caused by the same strain (9), and phony peach and plum leaf scald were positive in reciprocal transmissions by grafting (31). A citrus variegated chlorosis strain of $X$. fastidiosa produced leaf scorch disease in coffee (19). Reciprocal transmission between elm and sycamore leaf scorch strains were negative (26). These and a few other studies demonstrate the need for taxonomic characterization of $X$. fastidiosa at the pathovar level and for techniques to rapidly differentiate the pathovars. This is fundamental for further progress in studies on ecology, epidemiology, and control of these diseases. Characterization of $X$. fastidiosa at the subspecies level has begun with molecular techniques such as restriction fragment length polymorphisms (RFLPs) (3), randomly amplified polymorphic DNA (RAPD) $(5,13,21)$, and $16 \mathrm{~S}$ rDNA sequence analysis $(4,13)$. Currently, however, if a strain of $X$. fastidiosa is isolated from a new host, there is no rapid method to determine whether it is a new pathotype or a previously characterized one. The only option is reciprocal inoculation tests with a number of hosts, and this is too costly in space, time, and labor.

Sodium dodecyl sulfate-polyacrylamide gel electrophoresis (SDS-PAGE) of wholecell proteins has been a successful technique for the differentiation of bacterial pathovars by itself and in conjunction with other methods such as fatty acid analysis and DNA hybridization. SDS-PAGE of whole-cell proteins was used to differentiate and characterize Xanthomonas campestris pathovars (29) and phenotypically distinct groups of $X$. campestris pv. vesicatoria (1). Chang and Schaad (2) reported that the Pierce's disease, phony peach, plum leaf scald, elm leaf scorch, and periwinkle wilt strains of $X$. fastidiosa share many similarities with one another, but can still be differentiated by SDS-PAGE of whole-cell proteins. After cultures are grown, differentiation, or identification, of pathovars by SDS-PAGE would require only 1 to 2 days.

The objective of this research was to evaluate SDS-PAGE of whole-cell proteins as a method to rapidly differentiate and identify pathogenic types of $X$. fastidiosa.

\section{MATERIALS AND METHODS}

$X$. fastidiosa strains. $X$. fastidiosa strains with different hosts of origin were analyzed (Table 1). Strains were preserved at $-70^{\circ} \mathrm{C}$ in liquid PD3 (7) or PW+ $(6,27)$ with $15 \%$ glycerol and were grown to log phase on PD3 agar and/or PW+ agar medium.

Sample preparation. Strains of $X$. fastidiosa were characterized by onedimensional SDS-PAGE of whole-cell proteins according to the method of Laemmli (18). Log-phase cells of X. fastidiosa grown on PD3 or PW+ agar media were transferred into flasks containing 20 $\mathrm{ml}$ of liquid PW+. Flasks were incubated at $28^{\circ} \mathrm{C}$ for $48 \mathrm{~h}$, then placed on a rotary shaker $(100 \mathrm{rpm})$ at room temperature $\left(\sim 25^{\circ} \mathrm{C}\right)$ for 3 to 5 days. The number of days on the shaker varied with each 
strain/group, depending on rate of growth of the strain. Log-phase cultures (4 to 6 days incubation in PD3 for strains from grape or elderberry, 7 to 10 days incubation in PW+ for other strains) were harvested by centrifugation $(6,700 \times g$ for $15 \mathrm{~min})$. Cells were washed twice in sterile deionized water, after which the cell pellet was resuspended in $10 \%$ sorbitol. The suspension was adjusted to $A_{600 \mathrm{~nm}}=1.5$ to 1.8 with a spectrophotometer and mixed with an equal volume of a double-strength lysis buffer (125 mM Tris-hydrochloride, $\mathrm{pH}$ $6.8 ; 4 \%$ SDS; $10 \%$ 2-mercaptoethanol; $20 \%$ glycerol; and $0.01 \%$ bromophenol blue). Suspensions were heated at $95^{\circ} \mathrm{C}$ for

Table 1. List of Xylella fastidiosa strains assayed by sodium dodecyl sulfate-polyacrylamide gel electrophoresis (SDS-PAGE)

\begin{tabular}{|c|c|c|c|}
\hline Strain designation & Origin & Host & Source \\
\hline \multicolumn{4}{|l|}{ Group $1^{\mathrm{b}}$} \\
\hline $\begin{array}{l}\text { CONNCK1, UCLA-1, VINOF, } \\
\text { ATCC35877 }\end{array}$ & California & Vitis vinifera & 1,2 \\
\hline $\begin{array}{l}\text { PD88-5A, PD94-4, PD94-5, PD94-6, } \\
\text { PD94-7, PD94-8, PD94-9, PD94-10 }\end{array}$ & Arizona & V. vinifera & 3 \\
\hline $\begin{array}{l}\text { PD-1, PD-1r, PD-4, PD91-1, PD92-5, } \\
\text { PD92-6, PD92-8, PD92-9, PD93-1, } \\
\text { PD94-11, PD94-12, PD95-4, PD95-5, } \\
\text { PD95-6, PD95-7, PD95-8, PD95-9, } \\
\text { PD94-1, PD94-2, PD94-3, PD92-13, } \\
\text { PD95-1, ATCC35879, ATCC35881 }\end{array}$ & Florida & Vitis sp. & 3,2 \\
\hline PD94-13 & South Carolina & Vitis sp. & 3 \\
\hline ATCC49952 & North Carolina & V. rotundifolia & 2 \\
\hline PD91-2, PD95-2, PD95-3 & Florida & V. rotundifolia & 3 \\
\hline CB-9 & Florida & Citrus sinensis & 3 \\
\hline EB96-1 & Florida & Sambucus canadensis & 3 \\
\hline L95-1 & Florida & Lupinus aridorum & 3 \\
\hline ATCC35876 & Florida & Ambrosia artemisiifolia & 2 \\
\hline \multicolumn{4}{|l|}{ Group 2} \\
\hline $\begin{array}{l}\text { EB92-1, EB92-2, EB92-3, EB92-4, } \\
\text { EB92-5, EB95-1 }\end{array}$ & Florida & Sambucus canadensis & 3 \\
\hline \multicolumn{4}{|l|}{ Group 3} \\
\hline $\begin{array}{l}\text { Oak92-3, Oak92-4, Oak95-1,Oak92-6, } \\
\text { Oak92-7, Oak92-8 }\end{array}$ & Florida & Quercus laevis & 3 \\
\hline Oak92-10 & Florida & Q. nigra & 3 \\
\hline Oak88-9 & Florida & Q. virginiana & 3 \\
\hline Oak92-5 & Florida & Quercus sp. & 3 \\
\hline ATCC35874 & Wash., DC & Quercus sp. & 2 \\
\hline \multicolumn{4}{|l|}{ Group 4} \\
\hline OAN-1, OT5, OTR-TRI & California & Nerium oleander & 1 \\
\hline OLE98-1, OLE98-2 & Florida & N. oleander & 3 \\
\hline \multicolumn{4}{|l|}{ Group 5} \\
\hline BKB95-1 & Florida & Rubus sp. & 3 \\
\hline L95-2 & Florida & Lupinus villosus & 3 \\
\hline Syc86-1 & Florida & Platanus occidentalis & 3 \\
\hline ATCC35868, АTCC35869 & Massachusetts & Morus rubra & 2 \\
\hline ATCC 35870 & California & Prunus amygdalus & 2 \\
\hline ATCC35878 & Florida & Catharanthus roseus & 2 \\
\hline \multicolumn{4}{|l|}{ Group 6} \\
\hline ATCC 35873 & Wash., DC & Ulmus americana & 2 \\
\hline ATCC35871 & Georgia & Prunus salicina & 2 \\
\hline
\end{tabular}

a Sources of strains: 1 = A. H. Purcell, ESPM Insect Biology Division, University of California, Berkeley 94720; 2 = American Type Culture Collection, 12301 Parklawn Dr., Rockville, MD 20852; 3 = D. L. Hopkins, Mid-Florida REC, University of Florida, Apopka 32703.

${ }^{b}$ Groups are based on SDS-PAGE whole-cell protein profiles presented in this paper.

Table 2. Sodium dodecyl sulfate-polyacrylamide gel electrophoresis (SDS-PAGE) whole-cell protein profiles used to differentiate groups of Xylella fastidiosa strains

\begin{tabular}{lcccccc}
\hline $\begin{array}{l}\text { Protein band mass } \\
(\mathbf{k D a})\end{array}$ & Group 1 & Group 2 & Group 3 & Group 4 & Group 5 & Group 6 \\
\hline 22.0 & $+^{\mathrm{a}}$ & + & + & + & + & + \\
24.0 & + & + & + & + & + & + \\
25.8 & - & + & - & - & - & - \\
26.5 & - & - & - & + & - & - \\
27.0 & + & + & + & - & + & + \\
27.5 & - & - & - & + & - & - \\
29.5 & - & - & + & - & - & - \\
33.0 & - & - & - & + & + & + \\
33.5 & - & - & + & - & - & - \\
35.0 & - & - & - & - & - & + \\
\hline
\end{tabular}

${ }^{\mathrm{a}}+=$ presence of band in that group, $-=$ absence of band in that group.

10 min before loading on a discontinuous gel.

Electrophoresis of whole-cell proteins. The discontinuous gel was comprised of 40 $\mathrm{mm}$ of stacking gel on top of more than $100 \mathrm{~mm}$ of separation gel. The stacking gel formulation was $4 \%$ total acrylamide; 125 $\mathrm{mM}$ Tris-hydrochloride, $\mathrm{pH} 6.8$; and $0.1 \%$ SDS with $0.05 \%$ ammonium persulfate (fresh) and $0.1 \%$ tetramethylethylenediamine (TEMED) added after deaeration. The separation gel makeup was $10 \%$ total acrylamide; $375 \mathrm{mM}$ Tris-hydrochloride, $\mathrm{pH} 8.8$; and $0.1 \%$ SDS with $0.05 \%$ fresh ammonium persulfate and $0.05 \%$ TEMED added after deaeration. Suspensions were vortexed before loading. Wells were filled with $50 \mu \mathrm{l}$ of sample suspension. The standard was a low-range protein marker $(14,400$ to $97,400 \mathrm{Da})$ from BioRad laboratories.

Electrophoresis was carried out at $10^{\circ} \mathrm{C}$ in a Protean II xi slab vertical electrophoresis cell from BioRad filled with electrophoresis buffer $(25 \mathrm{mM}$ Tris, $192 \mathrm{mM}$ glycine, and $0.1 \%$ SDS, pH 8.3). A constant current of $25 \mathrm{~mA}$ per gel was applied until the bromophenol blue had reached the separation gel $(1.25 \mathrm{~h})$. The current was then increased to $35 \mathrm{~mA}$ per gel until the tracking dye had migrated about $100 \mathrm{~mm}$ through the separation gel (approximately $3.5 \mathrm{~h}$ ). The gels were removed from the slab and fixed in a mixture of $40 \%$ methanol, $10 \%$ glacial acetic acid, and 50\% deionized water. The gels were stained at room temperature by adding $0.1 \%$ Coomassie brilliant blue R-250 to a fresh mix of the above fixative solution. Gels were stained a minimum of $0.5 \mathrm{~h}$. They were observed on a white light viewing illuminator, then photographed prior to, or after subsequent destaining in the previously mentioned fixative solution. A Fisher camera (FB-PDC-34) with special hood attachments was used to document the results. Protein band masses were calculated by interpolation from the known standards. An average from all gels was calculated for the mass of the key bands used for analysis.

\section{RESULTS}

The SDS-PAGE whole-cell protein profiles of $75 \mathrm{X}$. fastidiosa strains (Table 1) were compared. Variations in the protein banding patterns among the strains were observed. Major differences were observed in proteins in the 21.5 to $45.0 \mathrm{kDa}$ molecular mass range, and these were used to differentiate among the strains. After analysis of the 75 strains by SDS-PAGE, it was found that the isolates could be consistently subdivided into six groups based on the presence or absence or difference in intensity of 10 protein bands (Tables 1 and 2).

All 41 strains originally obtained from grapevine (Vitis sp.) with Pierce's disease symptoms had identical protein profiles 
with three intensely stained bands at estimated molecular weights (MW) of 22,000, 24,000, and 27,000 (Fig. 1). A strain of $X$. fastidiosa obtained from ragweed (Ambrosia artemisiifolia), one from citrus (Citrus sinensis), one from scrub lupine (Lupinus aridorum), and one of seven strains from elderberry (Sambucus canadensis) also had this protein banding pattern.

Six of seven strains of $X$. fastidiosa from elderberry had the same three bands as the Pierce's disease strains plus an intense band at 25,800 MW (Fig. 2). Although a few other strains may have had a faint band of this MW, this intense band was unique to the elderberry strains. SDSPAGE protein profiles of $X$. fastidiosa strains from a variety of oak species (Quercus virginiana, Q. laevis, and $Q$. nigra) were identical (Fig. 3). These oak leaf scorch strains had five principal, intense bands that were consistently present. These included the three bands present in Pierce's disease strains plus additional bands at 29,500 and 33,500 MW. Both of these bands were unique to the oak strains.

The fourth group consisted of five oleander (Nerium oleander) strains. These strains had intense bands at 22,000, 24,000, 26,500, 27,500, and 33,000 MW (Fig. 4). This oleander leaf scorch group contained the only strains that did not possess the band at 27,000 MW. The bands at 26,500 and 27,500 were unique to these strains.

Whole-cell protein analysis by SDSPAGE identified four distinct pathogenic groups, but groups 5 and 6 consisted of miscellaneous strains that were pathogenic to various hosts (Table 1). The fifth group of $X$. fastidiosa strains had the three bands present in Pierce's disease strains plus an intense band at 33,000 MW (Fig. 4). Four ATCC strains with original hosts of Mada-

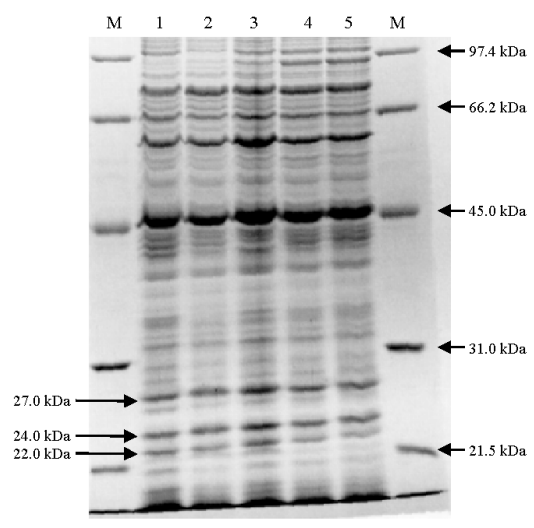

Fig. 1. Sodium dodecyl sulfate-polyacrylamide gel electrophoresis (SDS-PAGE) whole-cell protein profiles of Xylella fastidiosa strains from grapevine with Pierce's disease symptoms. Lane M, molecular weight marker; lane 1, PD-4; lane 2, PD92-13; lane 3, PD94-11; lane 4, PD94-12; lane 5, PD94-13. Markers and protein bands of importance to group 1 are indicated by arrows showing approximate molecular mass. gascar periwinkle (Catharanthus roseus), almond (Prunus amygdalus), and mulberry (Morus rubra) had this banding pattern. A strain from sycamore (Platanus occidentalis), blackberry (Rubus sp.), and lady lupine (Lupinus villosus) also were in this group. In group 6, there were two ATCC strains from plum (Prunus salicina) and elm (Ulmus americana) that had the same four bands as group 4 plus an additional band at 35,000 MW.

\section{DISCUSSION}

Whole-cell protein analysis by SDSPAGE of Xylella fastidiosa strains was shown to be a useful method for differentiating among some of the pathotypes. Consistent banding patterns were observed with the strains evaluated. Three of the groups could be differentiated on the basis of bands unique to their group. The intense $25.8-\mathrm{kDa}$ band was present only in the group 2 elderberry leaf scorch strains, the 29.5-kDa band was only in the group 3 oak leaf scorch strains, and the 26.5- and 27.5$\mathrm{kDa}$ bands occurred only in the group 4 oleander leaf scorch strains. Since the 25.8-, 26.5-, and 27.5-kDa bands are so close in mass to the $27.0-\mathrm{kDa}$ band that occurs in most strains, it is important to have a standard Pierce's disease strain on the gel next to unknown strains for comparison. The $29.5-\mathrm{kDa}$ band in the oak leaf scorch strains is easily identified, since there are no other intense bands near it.

There was complete uniformity of banding profiles in the 21.5 to $45.0 \mathrm{kDa}$ molecular mass range among the 41 Pierce's disease of grape strains (group 1); however, there were strains from four other hosts in this group. One of seven strains obtained from elderberry leaf scorch had the group 1 banding profiles. In an earlier study, this strain was more virulent on grapevine than on elderberry and was con-

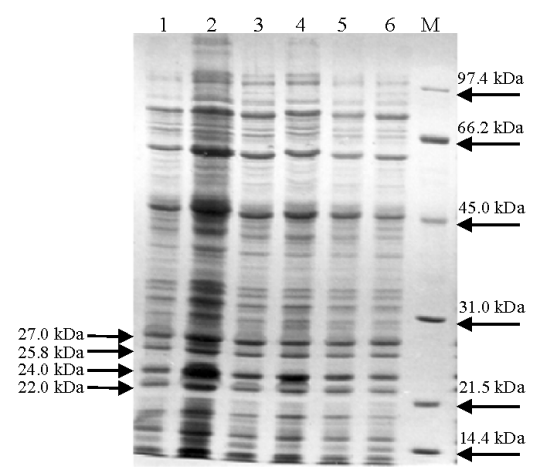

Fig. 2. Sodium dodecyl sulfate-polyacrylamide gel electrophoresis (SDS-PAGE) whole-cell protein profiles of Xylella fastidiosa strains from elderberry with leaf scorch symptoms. Lane 1, EB92-1; lane 2, EB92-2; lane 3, EB923; lane 4, EB92-4; lane 5, EB92-5; lane 6, EB95-1; lane M, molecular weight marker. Markers and protein bands of importance to group 2 are indicated by arrows showing approximate molecular mass. sidered to be a Pierce's disease pathotype that also can infect elderberry (17). The lupine strain (L95-1) and the strain from citrus (CB-9) also have been shown to be identical to grape strains in pathogenicity to grapevine (R. L. Wichman, unpublished; 14). It was a surprise that strain ATCC35876 originally from ragweed had the banding profile of the Pierce's disease group, because the ragweed stunt bacterium was reported originally to not infect grape, to not grow on PD-2 medium, and to be more closely related to plum leaf scald strains than to Pierce's disease strains (28). However, RFLP and RAPD studies of genetic relationships among $X$. fastidiosa strains have included the ragweed stunt strain in the Pierce's disease group $(3,21,25)$. ATCC35876 was pathogenic to grapevines (D. L. Hopkins, unpublished). All the strains in group 1, regardless of their hosts of origin, can be considered the Pierce's disease of grapevine pathotype (11).

The $6 X$. fastidiosa strains that cause typical elderberry leaf scorch (group 2), 10 oak leaf scorch strains (group 3), and 5 oleander leaf scorch strains (group 4) had uniform banding patterns within the groups. There were no variations in patterns related to geographical origin or, in the case of oak leaf scorch, to the original host oak species. Group 5 was made up of ATCC strains from various original hosts and three strains from blackberry, lupine, and sycamore in Florida, and did not appear to consist of a single pathogenic type. Group 5 consisted of seven strains from six different hosts. Not much is known about the cross pathogenicity of these strains to the different hosts. Genetic studies separated the almond and mulberry strains $(21,25)$. Group 6 consisted of an ATCC strain from plum leaf scald and one from

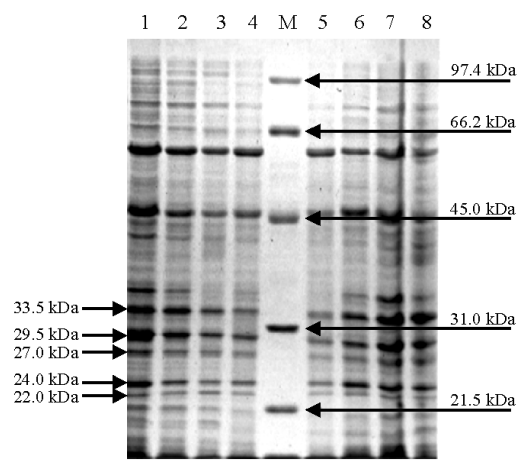

Fig. 3. Sodium dodecyl sulfate-polyacrylamide gel electrophoresis (SDS-PAGE) whole-cell protein profiles of Xylella fastidiosa strains from oaks with leaf scorch symptoms. Lane 1, Oak92-3; lane 2, Oak92-4; lane 3, Oak92-5; lane 4, Oak92-6; lane $M$, molecular weight marker; lane 5, Oak92-7; lane 6, Oak92-8; lane 7, Oak92-10; lane 8, Oak95-1. Markers and protein bands of importance to group 3 are indicated by arrows showing approximate molecular mass. 


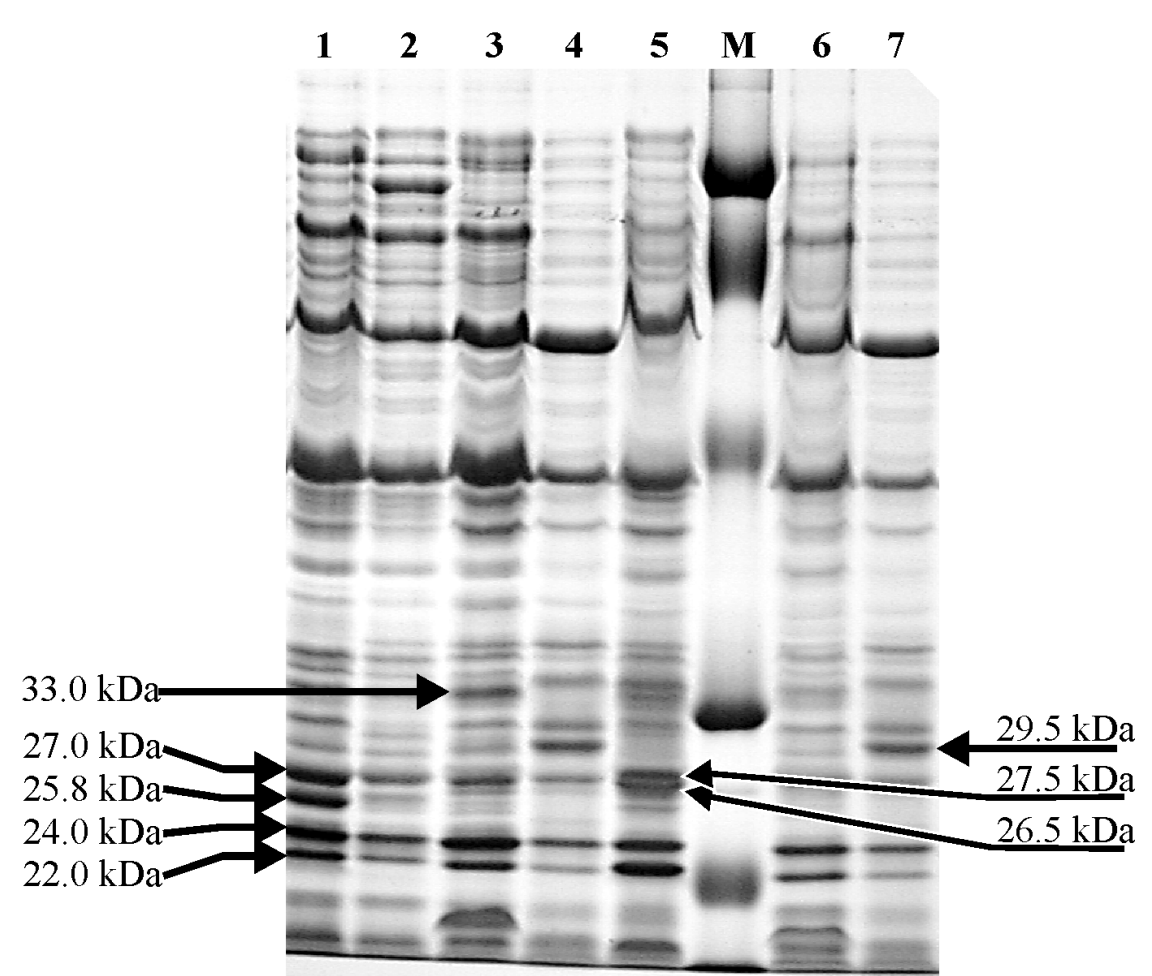

Fig. 4. Sodium dodecyl sulfate-polyacrylamide gel electrophoresis (SDS-PAGE) whole-cell protein profiles of Xylella fastidiosa strains from various hosts. Lane 1, EB92-3 from elderberry; lane 2, PD94-1 from grapevine; lane 3, L95-2 from lupine; lane 4, Oak92-6 from oak; lane 5, OAN-1 from oleander; lane M, molecular weight marker; lane 6, PD94-11; lane 7, Oak92-7. Markers and protein bands of importance in distinguishing groups 1 to 5 are indicated by arrows showing approximate molecular mass.

elm leaf scald. There is no information available on cross pathogenicity between these two strains, but a report on growth rates in culture indicated that these two strains were different (30).

In summary, whole-cell protein analysis by SDS-PAGE of $X$. fastidiosa strains was shown to be a rapid and consistent method for identifying four pathogenic groups of $X$. fastidiosa strains, including Pierce's disease of grapevine, elderberry leaf scorch, oak leaf scorch, and oleander leaf scorch. It was not effective in differentiating among several of the strains causing disease in various trees, such as mulberry leaf scorch, almond leaf scorch, and sycamore leaf scorch. Further research is being conducted to characterize the proteins that are unique to specific pathogenic groups of $X$. fastidiosa strains.

\section{ACKNOWLEDGMENTS}

We thank J. Charba and R. White for advice and counsel during this study, and D. Gray for the use of photography equipment and computer for scanning gels.

\section{LITERATURE CITED}

1. Bouzar, H., Jones, J. B., Minsavage, G. V., Stall, R. E., and Scott, J. W. 1994. Proteins unique to phenotypically distinct groups of Xanthomonas campestris pv. vesicatoria revealed by silver staining. Phytopathology 84:39-44.

2. Chang, C. J., and Schaad, N. W. 1982. Electrophoretic protein profiles of total cell envelopes of xylem-limited plant pathogenic
10. de Lima, J. E. O., Miranda, V. S., Hartung, J. S., Brlansky, R. H., Coutinho, A., Roberto, S. R., and Carlos, E. F. 1998. Coffee leaf scorch bacterium: Axenic culture, pathogenicity, and comparison with Xylella fastidiosa of Citrus. Plant Dis. 82:94-97.

11. Freitag, J. H. 1951. Host range of Pierce's disease virus of grapes as determined by insect transmission. Phytopathology 41:920934.

12. Hearon, S. S., Sherald, J. L., and Kostka, S. J. 1980. Association of xylem-limited bacteria with elm, sycamore, and oak leaf scorch. Can. J. Bot. 58:1986-1993.

13. Hendson, M., Purcell, A. H., Chen, D., Smart, C., Guilhabert, M., and Kirkpatrick, B. 2001. Genetic diversity of Pierce's disease strains and other pathotypes of Xylella fastidiosa. Appl. Environ. Microbiol. 67:895-903.

14. Hopkins, D. L. 1985. Physiological and pathological characteristics of virulent and avirulent strains of the bacterium that causes Pierce's disease of grapevine. Phytopathology 75:713-717.

15. Hopkins, D. L. 1989. Xylella fastidiosa: Xylem-limited bacterial pathogen of plants. Annu. Rev. Phytopathol. 27:271-290.

16. Hopkins, D. L., and Adlerz, W. C. 1988 Natural hosts of Xylella fastidiosa in Florida. Plant Dis. 72:429-431.

17. Hopkins, D. L., and Wichman, R. L. 2001. Pathogenic and molecular relationships among strains of Xylella fastidiosa from grapevine and American elder. Proc. PPB 2000. In press.

18. Laemmli, U. K. 1970. Cleavage of structural proteins during the assembly of the head of bacteriophage T4. Nature 227:680-685.

19. Li, W.-B., Pria, W. D., Jr., Teixeira, D. C., Miranda, V. S., Ayres, A. J., Franco, C. F., Costa, M. G., He, C.-X., Costa, P. I., and Hartung, J. S. 2001. Coffee leaf scorch caused by a strain of Xylella fastidiosa from citrus. Plant Dis. 85:501-505.

20. Minsavage, G. V., Thompson, C. M., Hopkins, D. L., Leite, R. M. V. B. C., and Stall, R. E. 1994. Development of a polymerase chain reaction protocol for detection of Xylella fastidiosa in plant tissue. Phytopathology 84:456-461.

21. Pooler, M. R., and Hartung, J. S. 1995. Genetic relationships among strains of Xylella fastidiosa from RAPD-PCR data. Curr. Microbiol. 31:134-137.

22. Pooler, M. R., and Hartung, J. S. 1995. Specific PCR detection and identification of Xylella fastidiosa strains causing citrus variegated chlorosis. Curr. Microbiol. 31:377-381.

23. Purcell, A. H. 1990. Homopteran transmission of xylem-inhabiting bacteria. Pages 243-266 in: Advances in Disease Vector Research, vol 5. K. F. Harris, ed. Springer-Verlag, New York

24. Purcell, A. H., and Hopkins, D. L. 1996. Fastidious xylem-limited bacterial plant pathogens. Annu. Rev. Phytopathol. 34:131151.

25. Qin, X., Miranda, V. S., Machado, M. A., Lemos, E. G. M., and Hartung, J. S. 2001. An evaluation of the genetic diversity of Xylella fastidiosa isolated from diseased citrus and coffee in São Paulo, Brazil. Phytopathology 91:599-605.

26. Sherald, J. L. 1993. Pathogenicity of Xylella fastidiosa in American elm and failure of reciprocal transmission between strains from elm and sycamore. Plant Dis. 77:190-193.

27. Sherald, J. L., Hearon, S. S., Kostka, S. J., and Morgan, D. L. 1983. Sycamore leaf scorch: Culture and pathogenicity of fastidious $\mathrm{xy}$ lem-limited bacteria from scorch-affected trees. Plant Dis. 67:849-852. 
28. Timmer, L. W., Brlansky, R. H., Lee, R. F., and Raju, B. C. 1983. A fastidious, xylemlimited bacterium infecting ragweed. Phytopathology 73:975-979.

29. Vauterin, L., Swings, J., and Kersters, K. 1991. Grouping of Xanthomonas campestris pathovars by SDS-PAGE of proteins. J. Gen. Microbiol. 137:1677-1687.

30. Wells, J. M., Raju, B. C., Hung, H. Y., Weisburg, W. G., Mandelco-Paul, L., and Brenner, D. J. 1987. Xylella fastidiosa gen. nov. sp. nov: Gram-negative, xylem-limited, fastidi- ous plant bacteria related to Xanthomonas spp. Int. J. Syst. Bacteriol. 37:136-143.

31. Wells, J. M., Raju, B. C., Thomson, J. M., and Lowe, S. K. 1981. Evidence of the common etiology of phony peach and plum leaf scald diseases. Phytopathology 71:1156-1161. 